\title{
KARAKTERISASI SUMBERDAYA PANGAN LOKAL SPESIFIK DAERAH DI KABUPATEN MUKOMUKO PROVINSI BENGKULU
}

\section{CHARACTERIZATION OF REGIONAL SPECIFIC LOCAL FOOD RESOURCES IN MUKOMUKO DISTRICT, BENGKULU PROVINCE}

\author{
Hesti Nur'aini'), Andika Saputra ${ }^{2)}$ \\ 1) Program Studi Teknologi Pertanian, Fakultas Pertanian, Universitas Dehasen Bengkulu \\ 2) PT. Alno Agro Utama Bengkulu \\ Email : hestinuraini@unived.ac.id
}

\begin{abstract}
ABSTRAK
Pangan lokal merupakan salah satu kekayaan alam yang mempunyai potensi cukup tinggi untuk dikembangkan demi kemajuan suatu daerah. Tujuan penelitian ini adalah untuk mengidentifikasi dan menganalisis makronutrien komoditas pangan lokal yang ada di Kabupaten Mukomuko Provinsi Bengkulu. Tahapan penelitian yang dilakukan meliputi identifikasi produk pangan lokal, inventarisasi metode pengolahan dan analisis makronutrien produk pangan lokal di Kabupaten Mukomuko. Analisis makronutrien yang dilakukan meliputi kadar karbohidrat, protein dan lemak. Hasil penelitian menunjukkan bahwa Kabupaten Mukomuko memiliki produk pangan lokal sebanyak 12 (dua belas) jenis, yang terdiri dari makanan atau lauk pauk sebanyak 6 (enam) jenis yaitu rendang lokan, sambal lokan, sate lokan, krasak mungkus, samba nioh, ikan kering kurau dan jajanan (cemilan) sebanyak 6 (enam) jenis yaitu juodak karyok, juodak sangengek, juodak itai, juodak sagon kering, atau kerupuk tortila. Hasil analisis makronutrien juodak itai menunjukkan kadar karbohidrat sebesar 25,29\%, kadar protein 4,62\% dan kadar lemak $8,63 \%$, sedangkan untuk juodak sangengek, menunjukkan kadar karbohidrat 18,14\%, kadar protein 3,12\% dan kadar lemak 22,36\%. Selanjutnya, juodak sagon pasir memiliki kadar karbohidrat 16,38\%, kadar protein 2,58\% dan kadar lemak 1,86\%.
\end{abstract}

Kata kunci : pangan lokal, Kabupaten Mukomuko, makronutrien

\section{ABSTRACT}

Local food is one of the natural resources that has a high enough potential to be developed. The purpose of this study was to identify and analyze macronutrients of local food commodities in Mukomuko District, Bengkulu Province. The stages of the research carried out included identification of local food products, inventory of methods for processing and analyzing macronutrient of local food products in Mukomuko District. Macronutrient analysis carried out included carbohydrate, protein and fat levels. The results showed that Mukomuko District had 12 (twelve) local food products, consisting of 6 (six) food or side dishes, namely rendang lokan, sambal lokan, satay lokan, krasak mungkus, samba nioh, dried fish kurau and snacks (snacks) of 6 (six) types, namely juodak karyok, juodak sangengek, juodak itai, dried juodak sagon, or tortilla crackers. The results of the macronutrient analysis of juodak itai showed carbohydrate content of $25.29 \%$, protein content of $4.62 \%$ and fat 
content of $8.63 \%$, while for juodak sangengek, showed carbohydrate content of $18.14 \%$, protein content of $3.12 \%$ and fat content $22.36 \%$. Furthermore, juodak sagon has $16.38 \%$ carbohydrate content, $2.58 \%$ protein content and $1.86 \%$ fat content.

Keywords : local food, Mukomuko District, macronutrient

\section{PENDAHULUAN}

Indonesia merupakan negara yang terdiri dari berbagai daerah yang memiliki keanekaragaman masing-masing. Keanekaragaman tersebut bisa meliputi budaya, tradisi, kepercayaan, adat istiadat dan makanan khas. Makanan khas atau pangan lokal suatu daerah selalu menyita banyak perhatian masyarakat dimana makanan merupakan salah satu kebutuhan pokok manusia. Beberapa jenis pangan lokal yaitu ketela pohon, sukun, jagung, kelapa dan lain-lain (Kasryno, 2013). Indonesia memiliki ragam seni dan budaya yang keberadaannya perlu dikembangkan dan dilestarikan agar tidak hilang ditelan waktu. Banyak makanan dari daerah luar Indonesia yang masuk dan kemudian dikenal oleh masyarakat Indonesia. $\mathrm{Di}$ Indonesia sendiri sebenarnya mempunyai begitu banyak jenis masakan, minuman, kudapan dari berbagai bahan dasar yang ada ditiap tiap daerah di Indonesia. Makanan khas daerah merupakan aset wisata bagi suatu daerah dan mempunyai peranan penting sebagai daya tarik wisatawan. Juga merupakan kekayaan bangsa di bidang kuliner (Cahyanto, 2012). Pangan adalah segala sesuatu yang berasal dari sumber hayati dan air, baik yang diolah maupun tidak diolah yang diperuntukan sebagai makanan atau mi numan bagi konsumsi manusia, termasuk bahan tambahan pangan, bahan baku pangan, dan bahan lain yang digunakan dalam proses penyiapan, pengolahan, dan/atau pembuatan makanan atau minuman (PP RI No.68 Thn 2002 dalam Suryana, 2008).

Pangan merupakan kebutuhan dasar yang paling esensial bagi manusia untuk mempertahankan hidup dan kehidupan. Pangan sebagai sumber zat gizi (karbohidrat, lemak, protein, vitamin, mineral, dan air) menjadi landasan utama bagi manusia untuk mencapai kesehatan dan kesejahteraan sepanjang siklus kehidupan. Pangan dikelompokkan menjadi dua yakni pangan hewani dan pangan nabati. Pangan hewani meliputi daging, ikan, kerang, telur, susu dan hasil susu. Sementara pangan nabati meliputi 1) serelia/ biji dan famili Gramineae, 2) Kacang-kacangan/biji dari famili 
Legumunoseae, 3) sayuran dalam bentuk akar-akaran, daun-daunan, pucuk-pucuk, labu dan sayur buah. 4) biji-biji an semua biji yang tidak termasuk serelia dan kacang-kacangan, 5) buah-buahan segar dan kering, bumbu dan rempahrempah, serta 6) pangan lainnya seperti madu, gula, jamur (Karsin, 2009 ).

Pangan lokal adalah makanan dan minuman yang biasa dikonsumsi oleh masyarakat tertentu, dengan citarasa khas yang diterima oleh masyarakat tersebut. Bagi masyarakat Indonesia umumnya amat diyakini khasiat, aneka pangan tradisional, seperti tempe, tahu, bawang putih, madu, temulawak, gadogado, kacang hijau, ikan laut, ikan darat dan lain-lain. Makanan tradisional Indonesia juga mengandung segi positif yang lain seperti: bahan- bahan yang alami, bergizi tinggi, sehat dan aman, murah dan mudah didapat, sesuai dengan selera masyarakat sehingga diyakini punya potensi yang baik sebagai makanan (Susanti, 2011).

Salah satu pilar dalam pembangunan pangan nasional kita adalah program penganeka-ragaman pangan atau disebut sebagai diversifikasi pangan. Seperti salah satu kutipan dari pidato Bung Karno, bahwa "Hidup matinya suatu bangsa ditentukan oleh ketahanan pangan negara". Namun, saat ini negara kita sedang mengalami permasalahan dalam meningkatkan ketahanan pangan terutama dampak krisis finansial bahkan perubahan iklim yang terjadi, harga pangan lokal seperti tidak terkendali dan membanjirnya pangan impor dipasar lokal, sehingga menyebabkan Indonesia yang tadinya kaya akan sumber daya lokal menjadi miskin akan kultur budaya mereka sendiri (Rauf, 2008).

Fokus masyarakat beralih ke pangan tunggal (beras) tanpa menghiraukan sumber daya lokal yang ada didaerah setempat. Kearifan lokal yang dimiliki setiap daerah seakan hanya menjadi simbol semata. Berbagai faktor yang dapat mempengaruhi lunturnya kegemaran sebagian masyarakat terhadap makanan tradisional Indonseia antara lain disebabkan karena adanya perubahan gaya hidup, perubahan sosial budaya, perkembangan ekonomi dalam kehidupan masyarakat, di samping itu kebiasaan masyarakat terhadap makan di luar, gencarnya promosi dan tersedianya makanan asing di berbagai kota besar juga sebagai salah satu faktor mengapa masyarakat lebih menyukai makanan asing dari pada makanan kita sendiri (Hariyadi, 2010).

Di Kabupaten Muko Muko Provinsi Bengkulu terdapat pangan lokal yang berpotensi untuk dikembangkan menjadi makanan tradisional, sebagai 
sumber daya pangan lokal.

Pengembangan sumber daya pangan lokal perlu dilakukan karena banyaknya penduduk pendatang yang berasal dari berbagai daerah dan untuk mendukung pengembangan dan pelestarian pangan lokal agar tetap terjaga serta produksi padi dengan jumlah lahan pertanian yang kian terbatas karena dialihfungsikan sebagai lahan pemukiman dan sebagai dambak bertani kelapa sawit, tidak akan mampu memenuhi kebutuhan pangan masyarakat Indonesia dan ditambah lagi pertambahan penduduk yang kian meningkat. PBB memperkirakan tahun 2030, 60\% penduduk akan tinggal di Kota. Ini artinya Sumber Daya Manusia untuk mengelola lahan pertanian pastinya kian sedikit karena semakin kurangnya daya tarik pertanian dan kenyataan adanya terjadi ketimpangan kesejahteraan terhadap petani. Jadi bila kita tetap mengkonsumsi beras sebagai pangan pokok masyarakat Indonesia maka yang akan terjadi adalah bencana kelaparan. Maka perlu diidentifikasi komoditas pangan lokal dengan tujuan untuk mengetahui jumlah dan jenis komoditas pangan lokal Kabupaten Muko Muko, kandungan gizi dan menetapkan produk yang potensial untuk dikembangkan di Kabupaten Muko Muko.

\section{METODE PENELITIAN}

\section{Bahan}

Bahan yang digunakan dalam penelitian ini adalah bahan survei dan bahan analisis kimia.

1. Bahan Survei

Bahan yang digunakan dalam survei adalah bahan yang digunakan untuk menginventarisir pangan lokal di Kabupaten Muko Muko berupa daftar pertanyaan, surat rekomendasi izin penelitian untuk mendapatkan informasi mengenai jenis dan komoditas pangan lokal Kabupaten Muko Muko.

2. Bahan Analisis Makronutrien

Bahan yang digunakan dalam analisis kimia adalah jenis dan pangan lokal Kabupaten Muko Muko hasil inventarisasi serta bahan-bahan kimia untuk analisis mutu produk pangan lokal.

\section{Alat}

Alat-alat yang digunakan dalam penelitian ini adalah :

\section{Alat Survei}

Alat yang digunakan dalam survei adalah pulpen, kertas, kamera, handphone sebagai alat gambar dan rekam suara mengenai jenis dan Komoditas pangan lokal Kabupaten Muko Muko.

2. Alat Analisis Kimia

Alat yang digunakan dalam analisis kimia adalah oven blower, slongsong, soxhlet, desikator, timbangan, alat 
kondensor, labu didih, labu khjedal, tabung didih dan Erlenmeyer.

\section{Cara Penelitian}

Penelitian ini dilakukan dalam tiga tahap yaitu :

1. Identifikasi produk pangan lokal di Kabupaten Muko Muko Provinsi Bengkulu.

Untuk mengidentifikasi produk pangan lokal di Kabupaten Muko Muko Provinsi Bengkulu dilakukan dengan cara survei yaitu dengan cara wawancara terhadap ketua adat sebanyak 1 orang, produsen sebanyak 5 orang, dan penjual pangan tradisional Kabupaten Muko Muko sebanyak 5 orang, dengan mendatangi dan mewawancarai responden secara langsung dengan menggunakan daftar pertanyaan.

2. Inventarisasi metode pengolahan produk pangan lokal

Untuk menginventarisasi metode pengolahan produk pangan lokal di Kabupaten Muko Muko Provinsi Bengkulu dilakukan dengan cara survei yaitu dengan cara wawancara terhadap produsen yang memproduksi pangan lokal Kabupaten Muko Muko mengenai bahan-bahan yang digunakan dan proses pengolahan bahan pangan tradisional tersebut.

3. Analisis makronutrien produk pangan lokal

Analisis makronutrien produk pangan lokal meliputi analisis kadar Protein, kadar karbohodrat, kadar lemak.

\section{Analisis Penelitian}

Analisis penelitian yang dilakukan adalah analisis deskriptif dan analisis kuantitatif.

1. Analisis Deskriptif

Mendeskripsikan jenis produk pangan lokal yang ada di Kabupaten Muko Muko Provinsi Bengkulu. Menurut Suyatno (2008), metode deskriptif adalah suatu metode dalam meneliti suatu objek, suatu kelompok manusia, kondisi suatu sistem pemikiran ataupun suatu kelas peristiwa pada masa sekarang dengan tujuan untuk membuat deskripsi, gambaran atau lukisan secara sistematis, faktual dan akurat mengenai fakta-fakta, sifat-sifat serta hubungan antar fenomena yang diselidiki.

2. Analisis Kuantitatif

Menganalisis sifat-sifat kimia produk pangan lokal yang ada di Kabupaten Muko Muko Provinsi Bengkulu. Menurut Sugiyono (2009) penelitian kuantitatif adalah metode penelitian yang berlandaskan pada filsafat positivisme, yang digunakan untuk meneliti pada populasi dan sampel tertentu, dimana teknik pengambilan sampel pada umumnya dilakukan secara 


\begin{abstract}
random, pengumpulan data menggunakan instrument penelitian, analisis data bersifat kuantitatif atau statistik dengan tujuan untuk menguji hipotesis yang telah ditetapkan.
\end{abstract}

\section{HASIL DAN PEMBAHASAN}

Jenis Sumber Daya Pangan Lokal di Kabupaten Mukomuko

Pangan lokal merupakan makanan tradisional suatu kelompok masyarakat Indonesia yang mencakup segala jenis makanan olahan asli baik dij adikan sebagai makanan utama, kudapan maupun minuman yang dikenal dan lazim di konsumsi masyarakat tersebut pada suatu wilayah spesifik dan sekaligus merupakan asset yang potensial dalam upaya penganekaragaman pangan untuk mewujudkan ketahanan pangan. Oleh karena itu produk makanan tradisional sudah saatnya mendapat perhatian dan mulai dikembangkan, sehingga mampu bersaing dengan makanan modern (Rosmiarti, 2016).

$$
\text { Pengembangan makanan }
$$

tradisional selain dimaksudkan sebagai upaya penganekaragaman penyediaan pangan, juga dalam rangka mengembangkan wisata Kabupaten
Mukomuko diharapkan dapat memperluas lapangan pekerjaan, peningkatan penghasilan dan kesempatan berusaha masyarakat khususnya di pedesaan Kabupaten Mukomuko, sehingga akan mendorong dan menumbuhkan perekonomian masyarakat setempat.

Berdasarkan informasi yang diberikan oleh tokoh adat, produsen, dan penjual di Kabupaten Mukomuko diperoleh jumlah pangan tradisional adalah sebanyak 12 (dua belas) jenis, yang terdiri dari: jumlah makanan atau lauk pauk adalah 6 (enam) jenis, jumlah jajanan (cemilan) adalah 6 (enam) jenis. Diketahui bahwa ada jenis makanan yang sama di beberapa kabupaten seperti juodak bajik yang menjadi makanan khas di Kabupaten Mukomuko namun juga diproduksi di Kabupaten Bengkulu Selatan, namun tetap dihitung jumlahnya. Hal ini dilakukan karena kemungkinan karakteristik makanan tersebut berbeda baik karena formula yang berbeda maupun cara pengolahannya yang juga berbeda. Nama-nama jenis pangan tradisional Kabupaten Mukomuko disajikan pada tabel 1. 
Tabel 1. Jenis Pangan Tradisional Kabupaten Mukomuko

\begin{tabular}{|l|l|l|}
\hline \multirow{2}{*}{ No } & \multicolumn{2}{|c|}{ Jenis Pangan Tradisional } \\
\cline { 2 - 3 } & \multicolumn{1}{|c|}{ Lauk Pauk } & \multicolumn{1}{c|}{ Jajanan } \\
\hline 1 & Rendang Lokan & Juodak Karyok \\
\hline 2 & Samba Lokan & Juodak Sangengek \\
\hline 3 & Sate Lokan & Juodak Bajik \\
\hline 4 & Kerasak Mungkus & Juodak Itai \\
\hline 5 & Samba Nioh & Juodak Sagun \\
\hline 6 & Ikan Kering kurau & Kerupuk Tortila \\
\hline
\end{tabular}

Sumber: Data Primer, 2017

Bahan-bahan yang digunakan dalam proses pembuatan pangan tradisioanal di Kabupaten Mukomuko bersumber dari daerah setempat (lokal) dan tidak menggunakan bahan pengawet dan pewarna sintetis. Jenisjenis bahan yang digunakan dan cara pengolahannya sangat bervariasi tergantung pada jenis pangan tradisional yang dibuat. Lokasi dominan produk pangan lokal ini masing masing makan disajikan pada tabel 2.

Berdasarkan jenis-jenis pangan tradisional Kabupaten Mukomuko di atas tidak semua jenis makanan tersedia setiap saat, namun dapat di temukan pada saat hari-hari besar seperti acara pernikahan, hari raya idul fitri, hari raya idul adha serta pada saat kunjungan dari berbagai instansi atau kepala daerah yang dianggap sebagai orang orang penting.
Jenis pangan lokal khas daerah Kabupaten Mukomuko golongan lauk pauk

\section{Rendang Lokan}

Potensi lokan di Kabupaten Mukomuko memiliki potensi pada pangan lokal yaitu lokan, sehingga banyak melahirkan jenis makanan yang bahan bakunya terbuat dari lokan yaitu rendang lokan. Rendang lokan merupakan sesuatu yang baru dan mungkin tidak kita temui di tempat lain.

\section{Samba Lokan}

Samba Lokan adalah makanan khas Kabupaten Mukomuko yang bahan bakunya terbuat dari lokan dengan cara disambal, biasanya digunakan masyarakat Kabupaten Mukomuko sebagai sayur atau campuran dari berbagai jenis gulai atau masakan berkuah. 
Tabel 2. Lokasi Tempat Dominan Pangan Tradisional Kabupaten Mukomuko

\begin{tabular}{|c|c|c|}
\hline No & Kecamatan & Jenis Pangan \\
\hline 1 & Lubuk Pinang & $\begin{array}{l}\text { Rendang Lokan, Samba Lokan, Kerasak } \\
\text { Mungkus, Samba Nioh, Juodak Karyok, } \\
\text { Juodak Sangengek, Juodak Bajik, Juodak Itai, } \\
\text { Juodak Sagun Kering, Kerupuk Tortila. }\end{array}$ \\
\hline 2 & Mukomuko Utara & $\begin{array}{l}\text { Rendang Lokan, Samba Lokan, Sate Lokan, } \\
\text { Kerasak Mungkus, Samba Nioh, Ikan Kering } \\
\text { kurau, Juodak Karyok, Juodak Sangengek, } \\
\text { Juodak Bajik, Juodak Itai, Juodak Sagun } \\
\text { Kering, Kerupuk Tortila. }\end{array}$ \\
\hline 3 & Teras Terunjam & $\begin{array}{l}\text { Rendang Lokan, Samba Lokan, Sate Lokan, } \\
\text { Kerasak Mungkus, Juodak Karyok, Juodak } \\
\text { Sangengek, Juodak Bajik, Juodak Itai, Juodak } \\
\text { Sagun Kering, Kerupuk Tortila. }\end{array}$ \\
\hline 4 & Pondok Suguh & $\begin{array}{l}\text { Rendang Lokan, Samba Lokan, Ikan Kering } \\
\text { kurau, Juodak Karyok, Juodak Sangengek, } \\
\text { Juodak Bajik, Juodak Itai, Juodak Sagun } \\
\text { Kering, Kerupuk Tortila. }\end{array}$ \\
\hline 5 & Ipuh & $\begin{array}{l}\text { Rendang Lokan, Samba Lokan, Kerasak } \\
\text { Mungkus, Samba Nioh, Ikan Kering kurau, } \\
\text { Juodak Karyok, Juodak Sangengek, Juodak } \\
\text { Bajik, Juodak Itai, Juodak Sagun Kering, } \\
\text { Kerupuk Tortila. }\end{array}$ \\
\hline 6 & Mukomuko Selatan & $\begin{array}{l}\text { Rendang Lokan, Samba Lokan, Sate Lokan, } \\
\text { Kerasak Mungkus, Samba Nioh, Ikan Kering } \\
\text { kurau, Juodak Karyok, Juodak Sangengek, } \\
\text { Juodak Bajik, Juodak Itai, Juodak Sagun } \\
\text { Kering, Kerupuk Tortila. }\end{array}$ \\
\hline
\end{tabular}

\section{Sate Lokan}

Sate lokan merupakan sesuatu yang baru dan mungkin tidak kita temui di tempat lain, dengan hasil masakan yang bisa memuaskan lidah konsumen dan pelanggan dan menjadi salah satu menu yang digemari para konsumen di Kabupaten Mukomuko. 


\section{Kerasak Mungkus}

Kerasak mungkus adalah jenis makanan yang terbuat dari ikan kecil-kecil yang berasal dari sungai atau air tawar. Kerasak Mungkus adalah juga termasuk kedalam masakan khas Kabupaten Mukomuko.

\section{Samba Nioh}

Samba nioh merupakan makanan khas Kabupaten Mukomuko yang terbuat dari kelapa parut. Cita rasa samba nioh hanya dapat dijumpai di Kabupaten Mukomuko. Bahan utama yang digunakan dalam pembuatan samba nioh adalah kelapa parut dan cabai.

\section{Ikan Kering Kurau}

Ikan Kering Kurau merupakan makanan khas Kabupaten Mukomuko yang terbuat dari ikan kurau yang dibelah dan dijemur. Bahan utama yang digunakan dalam pembuatan samba nioh adalah ikan kurau dan garam.

Berdasarkan hasil penelitian menunjukkan bahwa potensi sumber daya pangan lokal di Kabupaten Mukomuko untuk lauk pauk sebagian besar adalah berbahan baku pangan hewani yaitu kelompok pangan yang berbahan baku dari ikan. Masyarakat Kabupaten Mukomuko masih bertumpu pada pola pangan berbahan ikan, hal ini disebabkan oleh kondisi geografis Kabupaten Mukomuko adalah laut dan sungai sehingga kabupaten Mukomuko memiliki potensi sumber daya alam yang berasal dari laut dan sungai.

Menurut Suryana, (2003) produksi berbagai jenis pangan tidak dapat di hasilkan di semua wilayah dan tidak dapat dihasilkan setiap saat dibutuhkan. Namun berdasarkan potensi sumberdaya pangan lokal yang berkaitan dengan kondisi geografis daerah tersebut di sisi lain, konsumsi pangan dilakukan oleh semua penduduk dan setiap saat di butuhkan sehingga berbagai wilayah di tanah air masih dapat di kembangkan untuk memenuhi kebutuhan masyarakat setempat bahkan kebutuhan masyarakat daerah lain dan beberapa industri pangan ternyata mampu mengangkat citra dan cita rasa makanan tradisional yang ternyata sangat disukai berbagai kalangan.

\section{Golongan Jajanan \\ Juodak Karyok}

Juodak karyok adalah makanan ringan (sesuatu yang dimaksudkan untuk menghilangkan rasa lapar sementara waktu, memberi sedikit pasokan tenaga ke tubuh, atau sesuatu yang dimakan untuk dinikmati rasanya) yang bukan 
makanan utama (makan pagi, makan siang atau makan malam). Jodak karyok telah lama ada dan dikenal baik itu di daerah Mukomuko sendiri maupun di

\section{Juodak Sangengek}

Juodak sangengek adalah makanan ringan (sesuatu yang dimaksudkan untuk menghilangkan rasa lapar, juodak sangengek merupakan sebuah nama makanan dari Kabupaten Mukomuko, dimana bahan bakunya terbuat dari kelapa parut dicampur dengan tepung beras yang dibentuk bulat seperti lingkaran. Makanan tradisional ini biasa disuguhkan saat mengadakan jamuan pernikahan maupun kegiatan tradisi adat Mukomuko.

\section{Juodak Bajik}

Juodak bajik adalah makanan khas Kabupaten Mukomuko, dimana bahan bakunya terbuat dari beras ketan yang dicampur dengan santan dan gula merah, setelah adonan tersebut diaduk-aduk dan dibuat dalam bentuk empat persegi.

\section{Juodak Itai}

Juodak itai adalah sebuah nama makanan Kabupaten Mukomuko dimana komposisinya terdiri dari tepung gandum dicampur dengan telur ayam dan daerah sekitar seperti Bengkulu Utara.

Juadok karyok berbahan dasar dari beras ketan, yang diciptakan oleh masyarakat Mukomuko pengembang.

\section{Juodak Sagun}

Juodak sagun adalah salah satu jenis kue kering tradisional di Kabupaten Mukomuko yang cukup dikenal dari zaman dahulu hingga saat. Sesuai dengan namanya juodak sagun dibuat dengan bahan-bahan yang cukup sederhana dan mudah didapatkan. Dua bahan utama untuk membuat kue ini adalah tepung beras dan kelapa parut yang disangrai. Untuk membuat kue tradisional ini juga sangat mudah sekali prosesnya, sehingga sangat cocok dibuat untuk disajikan pada saat-saat tertentu atau pada saat hari raya. Rasa dari kue ini adalah manis dengan sensasi gurih dan rasa kelapa yang cukup dominan sehingga cocok dimakan sambil minum teh atau kopi.

\section{Kerupuk Tortila}

Kerupuk tortila adalah kudapan atau makanan ringan (sesuatu yang dimaksudkan untuk menghilangkan rasa lapar sementara waktu, memberi sedikit pasokan tenaga ke tubuh, atau sesuatu yang dimakan untuk dinikmati rasanya) yang bukan makanan utama 
(makan pagi, makan siang atau makan malam). Kerupuk tortila telah lama ada dan dikenal baik itu di daerah Mukomuko sendiri maupun di daerah sekitar seperti Bengkulu Utara. Kerupuk tortila berbahan dasar dari ubi kayu, yang diciptakan oleh masyarakat Mukomuko generasi ke generasi. Kerupuk tortila wujudnya seperti layaknya kerupuk, namun mempunyai cita rasa yang khas, renyah dan gurih, dan bisa dijadikan sebagai makanan ringan

Berdasarkan hasil penelitian menunjukkan bahwa potensi sumber daya pangan lokal di Kabupaten Mukomuko untuk jajanan adalah berbahan baku pangan padi-padian yaitu kelompok pangan yang yang berasal dari tanaman serelia yang biasa di konsumsi sebagai pangan pokok yaitu padi dan produk olahannya seperti tepung beras.

Masyarakat Kabupaten

Mukomuko masih bertumpu pada pola pangan pokok untuk jajanan yaitu beras, hal ini disebabkan oleh masyarakat Kabupaten Mukomuko memiliki mata pencaharian sebagai petani, kemudian dilihat dari faktor sosial ekonomi masyarakat Kabupaten Mukomuko dalam pengolahan jajanan memilih untuk mengeluarkan biaya seminimal mungkin atau efisiensi biaya, yang pada akhirnya memilih bahan baku yang mereka miliki dan mudah untuk diperoleh yaitu tepung beras, sehingga sampai sekarang bahan baku tepung beras menjadi warisan dari generasi ke generasi untuk pengolahan jajanan.

Menurut Suryana, (2003) bahwa bahan dasar makanan khas daerah belum beranjak dari pola pangan yang masih bertumpu pada pola pangan pokok yaitu beras. Hal ini disebabkan oleh beberapa faktor yakni : (1) rendahnya pengetahuan dan pemahaman masyarakat tentang pemanfaatan pola konsumsi pangan yang ber agam, bergizi dan berimbang serta aman atau yang di kenal dengan 3B A; (2) pangan spesial dan mengenyangkan sehingga cenderung sulit dalam melakukan perubahan ke pola pangan yang dianjurkan dalam pemenuhan gizi yang sehat. Selanjutnya disebabkan produksi berbagai jenis pangan tidak dapat dihasilkan di semua wilayah namun tergantung pada potensi daerah masing-masing dan tidak dapat dihasilkan setiap saat dibutuhkan.

\section{Kandungan Makronutrien Pangan}

\section{Lokal Kabupaten Mukomuko}

Pangan lokal adalah segala sesuatu yang berasal dari sumber hayati dan air, baik yang diolah maupun tidak diolah yang diperuntukan sebagai 
makanan atau minuman bagi konsumsi manusia, termasuk bahan tambahan pangan, bahan baku pangan, dan bahan lain yang digunakan dalam proses penyiapan, pengolahan, dan/atau pembuatan makanan atau minuman yang berasal daerah tertentu (Suryana, 2003).

Pangan lokal merupakan kebutuhan dasar yang paling esensial bagi daerah tersebut untuk mempertahankan hidup dan kehidupan. Pangan lokal sebagai sumber zat gizi (karbohidrat, lemak, protein, vitamin, mineral, dan air) menjadi landasan utama bagi manusia untuk mencapai kesehatan dan kesejahteraan sepanjang siklus kehidupan. Pangan dikelompokkan menjadi dua yakni pangan hewani dan pangan nabati. Pangan hewani meliputi daging, ikan, kerang, telur, susu dan hasil susu. Sementara pangan nabati meliputi 1) serelia/ biji dan famili Gramineae, 2) Kacang-kacangan/biji dari famili legumunoseae, 3) sayuran dalam bentuk akar-akaran, daun-daunan, pucuk-pucuk, labu dan sayur buah. 4) biji-biji an semua biji yang tidak termasuk serelia dan kacang-kacangan, 5) buah-buahan segar dan kering, bumbu dan rempah-rempah, serta 6) pangan lainnya seperti madu, gula, jamur (Karsin, 2009 ).

Hasil analisis kandungan makronutrien pangan lokal Kabupaten Mukomuko diketahui kandungan gizi sangat beragam yaitu tergantung dari jenis lauk pauk, jajanan dan minuman. Pada saat penelitian diperoleh jumlah pangan tradisional adalah sebanyak 12 (dua belas) jenis, yang terdiri dari: jumlah makanan atau lauk pauk adalah 6 jenis, jumlah jajanan (cemilan) adalah 6 (enam) jenis, namun dalam penelitian yang dilakukan oleh peneliti hanya 3 (tiga) jenis pangan lokal saja yaitu juodak itai, juodak sangengek, dan juodak sagon pasir. Hal ini dilakukan karena jenis pangan lokal yang diteliti adalah alasan bahwa dalam penelitian ini hanya fokus pada makanan ringan dan karena keterbatasan biaya dalam penelitian ini. Kemudian jajanan kering, memiliki umur simpan yang relatif lama, sehingga berpotensi untuk dijadikan sebagai makanan oleh-oleh khas Kabupaten Mukomuko. Kandungan makronutrien pangan lokal Kabupaten Kaur disajikan pada tabel 3 . 
Tabel 3. Kandungan Makronutrien Pangan Lokal Kabupaten Mukomuko

\begin{tabular}{|c|l|c|c|c|}
\hline No & $\begin{array}{l}\text { Jenis Pangan Tradisioanal } \\
\text { Kabupaten Mukomuko }\end{array}$ & $\begin{array}{c}\text { Karbohidrat } \\
\mathbf{( \% )}\end{array}$ & $\begin{array}{c}\text { Protein } \\
\mathbf{( \% )}\end{array}$ & $\begin{array}{c}\text { Lemak } \\
\mathbf{( \% )}\end{array}$ \\
\hline 1 & Juodak itai & 25,29 & 4,62 & 8,63 \\
\hline 2 & Juodak Sangengek & 18,14 & 3,12 & 22,36 \\
\hline 3 & Juodak Sagon Pasir & 16,38 & 2,58 & 1,86 \\
\hline
\end{tabular}

Berdasarkan tabel 3 diketahui bahwa hasil uji laboratorium terhadap kandungan gizi pangan tradisional di Kabupaten Mukomuko cukup beragam yang terdiri dari yaitu juodak itai, juodak sangengek, dan juodak sagon pasir. Untuk jenis juodak itai memiliki kandungan karbohidrat 25,29\%, kandungan protein 4,62\%, dan kandungan lemak 8,63\%. Untuk jenis jajanan juodak sangengek memiliki kandungan karbohidrat 18,14\%, kandungan protein $3,12 \%$, dan kandungan lemak 22,36\%. Untuk jenis juodak sagon pasir memiliki kandungan karbohidrat 16,38\%, kandungan protein 2,58\%, dan kandungan lemak 1,86\%

\section{Kadar Karbohidrat}

Berdasarkan hasil penelitian diketahui bahwa juodak itai memiliki memiliki kadar karbohidrat 25,29\%, dibandingkan dengan kondisi standar kue telur gabus, menurut (SNI 2007), kadar karbohidrat kue telur gabus maksimal
$65 \%$ dan ternyata hasil penelitian pada pembuatan juodak itai menunjukkan bahwa kadar karbohidrat tersebut sudah masuk kedalam standar (SNI).

Kemudian jajanan juodak sangengek memiliki kadar karbohidrat $18,14 \%$, dibandingkan dengan kondisi standar kue gapit, menurut (SNI 1992), karbohidrat maksimal kue gapit $70 \%$ dan ternyata hasil penelitian pada pembuatan juodak sangengek menunjukkan bahwa kadar karbohidrat tersebut sudah masuk kedalam standar (SNI).

Untuk jajanan juodak sagon pasir memiliki kadar karbohidrat $16,38 \%$, dibandingkan dengan kondisi dengan kondisi standar kue sagon bakar, menurut (SNI 01-4475-1998), kadar karbohidrat kue sagon bakar adalah maksimal $73 \%$ dan ternyata hasil penelitian pada pembuatan sagun menunjukkan bahwa kadar karbohidrat tersebut sudah masuk kedalam standar (SNI).

Penetapan kandungan karbohidrat 
pada makanan perlu dilakukan untuk mengetahui kondisi bahan pangan tersebut. Karbohidrat dalam makanan berguna sebagai sumber kalori atau energi dan sebagai sumber serat bagi makhluk hidup (Rivai, 2005). Karbohidrat adalah sumber energi utama bagi tubuh manusia. Manusia memenuhi kebutuhan karbohidrat setiap harinya dari makanan pokok yang dikonsumsi, seperti dari beras, jagung, sagu, ubi, dan lain sebagainya. Akan tetapi bukan berarti karbohidrat hanya terdapat pada golongan bahan makanan yang telah disebutkan di atas, pada golongan buah dan beberapa jenis sayur dan kacangkacangan juga terdapat kandungan karbohidrat meskipun kandungannya tidak sebanyak golongan serealia dan umbi (Apriyanto,1999).

\section{Kandungan Protein}

Berdasarkan hasil penelitian diketahui bahwa juodak itai memiliki memiliki kandungan protein 4,62\%, dibandingkan dengan kondisi standar kue telur gabus, menurut (SNI 2007), kadar protein minimal kue telur gabus $3,48 \%$ dan ternyata hasil penelitian pada pembuatan juodak itai menunjukkan bahwa kadar protein tersebut sudah masuk kedalam standar (SNI).

Kemudian jajanan juodak sangengek memiliki kadar protein
$3,12 \%$, dibandingkan dengan kondisi standar kue gapit, menurut (SNI 1992), protein maksimal kue gapit 9\% dan ternyata hasil penelitian pada pembuatan juodak sangengek menunjukkan bahwa kadar protein tersebut sudah masuk kedalam standar (SNI).

Untuk jajanan juodak sagon pasir memiliki kadar protein $16,38 \%$, dibandingkan dengan kondisi standar kue sagon bakar, menurut (SNI 014475-1998), kandungan protein kue sagon bakar adalah maksimal $45 \%$ dan ternyata hasil penelitian pada pembuatan sagun menunjukkan bahwa kadar karbohidrat tersebut sudah masuk kedalam standar (SNI).

Penetapan kandungan karbohidrat pada makanan perlu dilakukan untuk mengetahui kondisi bahan pangan tersebut. Karbohidrat dalam makanan berguna sebagai sumber kalori atau energi dan sebagai sumber serat bagi makhluk hidup (Rivai, 2005). Protein merupakan polimer yang panjang dari asam-asam amino yang bergabung melalui ikatan peptida. Komposisi ratarata unsur kimia yang terdapat dalam protein adalah karbon 55\%, hidrogen $7 \%$, oksigen $23 \%$, nitrogen $16 \%$, sulfur $1 \%$ dan kurang dari $1 \%$ fosfor (Winarno, 1991; Tarigan, 1983). Protein nabati adalah protein yang berasal dari tumbuh-tumbuhan. Contoh jagung, 
kacang kedelai, kacang hijau, dan jenis kacang-kacangan lainnya yang mengandung protein tinggi. Kacang kedelai merupakan sumber protein nabati yang mempunyai mutu atau nilai biologi tertinggi dan sedangkan yang relatif rendah mutunya dalam sumber protein adalah padi-padian dan hasilnya.

\section{Kadar lemak}

Berdasarkan hasil penelitian diketahui bahwa juodak itai memiliki memiliki kandungan lemak 8,63\%, dibandingkan dengan kondisi standar kue telur gabus, menurut (SNI 2007), kandungan lemak kue telur gabus maksimal 30,42\% dan ternyata hasil penelitian pada pembuatan juodak itai menunjukkan bahwa kandungan lemak tersebut sudah masuk kedalam standar (SNI).

Kemudian jajanan juodak sangengek memiliki kandungan lemak 22,36\%, dibandingkan dengan kondisi standar kue gapit, menurut (SNI 1992), kandungan lemak minimal kue gapit 9,5\% dan ternyata hasil penelitian pada pembuatan juodak sangengek menunjukkan bahwa kadar protein tersebut sudah masuk kedalam standar (SNI).

Untuk jajanan juodak sagon pasir memiliki kandungan lemak $1,86 \%$, dibandingkan dengan kondisi standar kue sagon bakar, menurut (SNI 01-4475-1998), kandungan lemak kue sagon bakar adalah maksimal 8\% dan ternyata hasil penelitian pada pembuatan juodak sagon menunjukkan bahwa kadar karbohidrat tersebut sudah masuk kedalam standar (SNI).

Penetapan kandungan lemak pada makanan perlu dilakukan untuk mengetahui kondisi bahan pangan tersebut. Kandungan lemak berfungsi sebagai globula yang melapisi protein. Protein dan lemak efektif untuk meningkatkan komponen secara konsisten. Protein yang dilapisi lemak dapat menghasilkan gel atau pasta lebih kuat sehingga dapat meningkatkan viskositas (Soetrisno, 2008). Menurut Suhardjo (2008) gugus metil pada CMC yang bersifat tidak polar cenderung mengikat lemak yang bersifat tidak polar.

Kadar lemak merupakan salah satu sumber utama energi dan mengandung lemak esensial. Namun konsumsi lemak berlebihan dapat merugikan kesehatan, misalnya kolesterol dan lemak jenuh. Dalam berbagai makanan, komponen lemak memegang peranan penting yang menentukan karakteristik fisik keseluruhan, seperti aroma, tekstur, rasa dan penampilan. Karena itu sulit untuk menjadikan makanan tertentu 
menjadi rendah lemak (low fat), karena jika lemak dihilangkan, salah satu karakteristik fisik menjadi hilang. Lemak juga merupakan target untuk oksidasi, yang menyebabkan pembentukan rasa tak enak dan produk menjadi berbahaya. Preparasi sampel pada analisis lemak tergantung pada jenis makanan yang dianalisis, sifat komponen lemak dan jenis prosedur analisis yang digunakan (seperti ekstraksi solven, ekstraksi non-solven, instrumentasi). Untuk menentukan prosedur preparasi sampel, perlu diketahui struktur fisik dan lokasi lemak penting dalam makanan (Winarno 2009).

\section{KESIMPULAN}

Hasil penelitian menunjukkan bahwa Kabupaten Mukomuko memiliki jumlah pangan tradisional adalah sebanyak 12 (dua belas) jenis, yang terdiri dari: jumlah makanan atau lauk pauk adalah 6 (enam) jenis yaitu rendang lokan, samba lokan, sate lokan, kerasak mungkus, samba nioh, ikan kering kurau. Sedangkan untuk jumlah jajanan (cemilan) adalah 6 (enam) jenis juga yaitu juodak karyok, juodak sangengek, juodak bajik, juodak itai, juodak sagun kering, kerupuk tortila.

Kandungan makronutrien komoditas pangan lokal yang ada di Kabupaten Mukomuko

Provinsi
Bengkulu, berdasarkan hasil uji laboratorium terhadap kandungan gizi pangan tradisional cukup beragam, untuk jenis juodak itai memiliki kandungan karbohidrat 25,29\%, kandungan protein 4,62\%, dan kandungan lemak $8,63 \%$. Untuk jenis jajanan juodak sangengek memiliki kandungan karbohidrat 18,14\%, kandungan protein $3,12 \%$, dan kandungan lemak 22,36\%. Untuk jenis juodak sagon pasir memiliki kandungan karbohidrat $16,38 \%$, kandungan protein $2,58 \%$, dan kandungan lemak $1,86 \%$.

\section{DAFTAR PUSTAKA}

Cahyanto. 2012. Penguatan Kearifan Lokal sebagai Solusi Permasalahan Ketahanan Pangan Nasional. https:icssis. Files. Wordpress.com.2012.pdf. Diakses 7 Januari 2017.

Hariyadi, P. 2010. Penguatan Industri Penghasil Nilai Tambah Berbasis Potensi Lokal. IPB Press. Bogor

Karsin, E.S. 2009. Peranan Pangan dan Gizi dalam Pembangunan. Penebar Swadaya. Jakarta.

Kasryno, et al. 2013. Aneka Macam Produk Olahan Jagung. Yogyakarta : Kanisius.

Latief, D. 2010. Konsumsi Pangan Tingkat Rumah Tangga Sebelum dan Selama Krisis Ekonomi. Widyakarya Nasional Pangan dan Gizi.VII. Lembaga Ilmu pengetahuan Indonesia. Jakarta.

Lestari, Puji A,S., Maksum, M., Widodo, K.H. 2012. Peran Makanan Tradisional Berbahan Baku Ubi Kayu terhadap Sistem Ketahanan Pangan Ditinjau dari Perspektif Ekonomi Rumah Tangga. Skripsi. 
Program Studi Agribisnis. Universitas Bengkulu. Bengkulu.

Rauf, W.A. dan S.L. Martina. 2008.Pemanfaatan Komoditas

Pangan Lokal sebagai Sumber Pangan Alternatif di Papua. Balai Pengkajian Teknologi Pertanian Papua. Papua.

Rosmiarti. 2011. Identifikasi Makanan Khas Provinsi Bengkulu. Prosiding Semitra Bidang Ilmu-ilmu BKSPTN Wilayah Barat. Vol 5.

Soetrisno.2008.

Pembangunan

Pertanian dan Pengembangan

Agroindustri. Pertanian dan Pangan. Pustaka Sinar Harapan. Jakarta.

Suryana, Ahmad. 2008. Kapita Selekta. Evaluasi Pemikiran Kebijakan Ketahanan Pangan. Yogyakarta: BPFE-Yogyakarta.

Susanti. 2011. Identifikasi Makanan
Khas Provinsi Bengkulu Berbahan Dasar Ikan. Prosiding Semitra Bidang Ilmu-ilmu BKSPTN Wilayah Barat. Vol 2. Sugiyono. 2009. Statistika Untuk Penelitian. Bandung: Alfabeta.

Suhardjo. 2008. Pola Konsumsi Pangan dan Gizi Penduduk Indonesia. Departemen Gizi Masyarakat FEMA IPB dan Badan Litbangkes Kemenkes RI. Bogor.

Suyatno. 2008. Metodologi Penelitian Sosial. Edisi Revisi. Kencana Prenada Media. Indonesia.

Syamsir, E. 2011. Pangan Tradisioanal Indonesia. www.ipb.ac.id. 4 Januari 2017.

Winarno. 2009. Kimia Pangan dan Gizi. PT. Gramedia Pustaka Utama. Jakarta. 